\title{
TERVETULLUT LISÄ KIRJOITUSTYÖN OPPAIDEN JOUKKOON
}

\author{
Pirkko Niemelä, Kirsti La- \\ gerspetz, Kari Lagerspetz, Ris- \\ to Näätänen 1991. Miten kir- \\ joitan tieteellisen artikkelin. \\ WSOY. 115 sivua.
}

Niemelä, Lagerspetz \& Lagerspetz ja Näätänen ovat kirjoittaneet teoksen tieteellisen artikkelin teosta. Kirjan tarkoituksena on antaa tietoa siitä, minkälaisia sisällöllisiä ja muodollisia vaatimuksia on tieteellisellä artikkelilla, joka on tasoltaan kansainvälinen ja jonka julkaisemista kansainvälisessä tieteellisessä aikakauslehdistössä artikkelin kirjoittaja voi toivoa. Teos ei ole reseptiopas, vaan siinä käydään läpi kirjoittamista osana tutkimusprosessia sekä tutkijan ja kansainvälisen tiedeyhteisön vuorovaikutusta. Kirjoittajat ovat psykologian ja biologian edustajia, mutta tämä ei rajaa teoksen käyttökelpoisuutta muiden tieteenalojen suhteen.

Kirjasta saa sen kuvan, että se on tehty lähinnä jatko-opiskelijoiden ja tutkijoiden tarpeita ajatellen, mutta mikään ei estä käyttämästä teoksessa esitettyjä periaatteita minkä tahansa opiskeluvaiheen apuna: hyvän ja selkeän kirjoittamisen säännöt ovat melko yleispäteviä. Kirjoittajat toteavat, että kommunikointi kansainvälisen tutkijayhteisön kanssa on välttämätöntä jokaiselle tutkijalle, joka ottaa tieteellisen työnsä vakavasti. Kansainvälinen tutkijayhteisö kommunikoi keskenään pääasiassa korkeatasoisten kansainvälisten tieteellisten julkaisujen kautta. Kirjoittamalla kansainvälisiin julkaisuihin saa yhteyden oman alansa parhaisiin tutkijoihin.

\section{Arviointimenettely}

Teoksessa selostetaan suhteellisen laajasti arvioijamenettelyä, jota kaikki arvostetuimmat kansain- väliset julkaisut käyttävät. Arvioijamenettelyssä julkaistavaksi tarjottu juttu lähetetään lehden toimituksesta yhdelle tai useammalle alan asiantuntijalle arvioitavaksi, mikäli lehden toimitus katsoo, että se ylipäänsä kannattaa lähettää arvioitavaksi. Arvioijina arvostetut lehdet pystyvät käyttämään tieteenalan huippuasiantuntijoita. Asiantuntija antaa artikkelista kirjallisen palautteen, jonka pituus saattaa olla yhdestä kymmeneen liuskaan. Lehden toimituksesta arviointi lähetetään edelleen artikkelin kirjoittajalle ilman arvioinnin tehneen asiantuntijan nimeä: näin vältetään se, että arvioijalla olisi rasitteita esittää kritiikkiä kirjoittajalle.

Arvioija saa joissakin tapauksissa tietää kirjoittajan nimen, joissain taas ei. Subjektiivisesti arvioiden arvioijan ja artikkelin kirjoittajan ei pitäisi saada tietää toistensa nimiä, koska silloin voisi olettaa artikkelin sisällön painoarvon olevan suurimmillaan ilman mitään muita, usein toisarvoisia kriteereitä.

Saatuaan arvioinnin artikkelistaan kirjoittaja voi sen pohjalta alkaa parannella artikkeliaan, mikäli se on arvioijan varauksin periaatteessa hyväksytty lehteen. Kirjoittaminen-arviointi -sykli voi toistua muutamaankin kertaan, varsinkin jos artikkelissa on paljon sellaista, johon arvioija on puuttunut.

Arviointiin alistuminen on monelle suomalaiselle tutkijalle kirjoittajien mukaan vaikeaa, sillä työllä ja vaivalla tehtyä juttua ei haluttaisi jättää tuntemattomiksi jäävien asiantuntijoiden reposteltavaksi. Arvioijamenettelyn käytöllä on kuitenkin selvät etunsa: artikkelin kirjoittaja saa yksityiskohtaisen palautteen, jonka antaa alan asiantuntija usein varsin tarkan artikkeliin perehtymisen jälkeen; arvioijamenettelyä käyttävän lehden tieteellinen taso on todennäköisesti parempi kuin sellaisen, joka ei menettelyä käytä ja julkaistun artikkelin meriittiarvokin on kirjoittajalle hyvä; tutkijan työn tulokset ovat jatkuvan arvioinnin alaisia ja arviointi antaa kirjoittajalle mahdollisuuden kehittyä tutkijana. 


\section{Lähdeaineisto}

Teoksessa annetaan ohjeita lähdeaineiston hakuun sekä käsi- että tietokonehakua käyttäen sekä itse kirjoittamisprosessin läpivientiin. Kirjallisuuden hakua koskeva luku on lyhyt, mutta tiivis ja hyvin ajan tasalla. Eri artikkelityypit luonnehditaan myös ja annetaan neuvoja niiden teknisen rakenteen suhteen. Englannin kielellä kirjoittamisesta on oma lukunsa, koska se on nykyään tieteen yleiskieli kuten keskiajalla oli latina — jopa saksalaisen kielialueen parhaat työt pyritään kirjoittajien mukaan julkaisemaan englanninkielisissä lehdissä.

Kirja on tervetullut lisä kirjoitustyön oppaiden joukkoon. En ole huomannut, että muita suomenkielisiä kirjoja olisi tehty vastaavaan tarkoitukseen, siis ohjeiksi kansainväliset vaatimukset täyttävien artikkelien kirjoittamiseksi. Teos palvellee käsikirjatyyppisenä asiasta kiinnostuneita.

Kirja on pehmeäkantinen ja kätevän kokoinen, avattuna hieman A4-kokoa pienempi. Hieman ihmetyttää, miksi sisällysluettelo on kirjan lopussa, mutta ehkä siihen on painotekniset syyt. Ainakin itse olen tottunut hakemaan nykyisistä kirjoista sisällysluetteloa kirjan alusta ja asiasanastoa kirjan lopusta. Asiasanastoa tästä teoksesta ei tosin löydy sen paremmin alusta kuin lopustakaan, mutta sisällysluettelo on niin hienojakoinen ja kirja niin pieni sivumäärältään, että haluttu asia löytyy nopeasti ilman sitäkin. Kirjan kieli on hyvää proosaa. Englanninkielisissä julkaisuissa käytetyt käsitteet, esimerkiksi erilaiset artikkelityypit, on selostettu selvästi ja täsmällisesti.

\section{Aikuiskasvatuksen parhaita kansainvälisiä tiedelehtiä}

Erilaisia arvostettuja aikuiskoulutusalan kansainvälisiä julkaisuja ovat esimerkiksi Adult Education Quartely, Studies in the Education of Adults, International Journal of Lifelong Education ja Canadian Journal for the Study of Adult Education. Kaikki mainitut käyttävät artikkeleissa hyväkseen arviointimenettelyä. 